\title{
ESTUDO DOS CONDICIONAMENTOS GEOQUIMICOS QUE PODEM LEVAR A CIMENTAÇĀO DE FILTROS DE BARRAGENS PELO FERRO
}

Carlos Leite Maciel Filho

Departamento de Geociências. Centro de Ciências Naturais e Exatas. UFSM. Santa Maria, RS.

RESUMO

Atravēs de um estudo teōrico aliado a observação de fatos geológicos explica-se o fenômeno de cimentação de filtros de barra gens pelo ferro. São levados em conta conhecimentos de limnologia, geoquímica e biogeoquímica do ferro, ocorrēncia de crostas ferrugi nosas e fluxo da āgua em barragens de terra.

\section{SUMMARY}

MACIEL FILHO, C.L., 1983. Study of geochemichal conditioning which leads to dam filter cimentation by iron. Ciência e Naturas $5: 25-43$.

A theoretical study with observation of geological events justify the dam filter cimentation by iron. Knowledge of limnology, geochemistry and biogeochemistry of iron, occurence of ferriginous crust, water flow by earth dams, are taked into account.

INTRODUÇÃO

A precipitação de compostos ferruginosos em filtros de bar ragens tem comprovação em alguns casos como na barragem do Rio Gran de (Infanti \& Kanji, 13; Guerra, 7) e vem preocupando o meio geotécni co, como no XI Seminärio Nacional de Grandes Barragens (0liveira \& Camargo, 21 ).

De 1977 a 1982 foi desenvolvida uma pesquisa ligada ao Cur so de Pós-Graduação em Geociências na Universidade de São Paulo só bre o processo geoquỉmico de obstrução de filtro de barragens (Ma ciel Filho, 18), incluindo revisão das teorias e estudos relaciona dos, levantamentos de campo e experimentos de laboratōrio. Neste ar tigo è apresentada apenas a primeira fase, sendo seu objetivo demons trar que os conhecimentos de limnologia, geoquímica e biogeoquímica do ferro combinados com o estudo do fluxo da āgua em barragens e exemplos de natureza geológica explicam o fenōmeno observado de cị mentação pelo ferro.

\section{GEOQUIMICA DO FERRO NAS AGUAS SUPERFICIAIS E SUB-SUPERFICIAIS}

Abundância do ferro

0 ferro é um dos elementos mais comuns, com uma abundância média na crosta de 5,6 \% (Krauskopf, 15), só inferior ao oxigênio, 
silício e alumínio, davindo aí, em grande parte, a sua importāncia. Destaque-se que os solos de climas tropicais e sub-tropicais são mais ricos em ferro. Se este fosse totalmente inerte, não teria possibili dade de provocar a cimentação de filtros durante a vida útil de uma barragem. Mas como será demonstrado, $\bar{e}$ um elemento reativo e móvel no meio ambiente em questão.

oxidagão-redução e equagão de Nernst

A geoquímica do ferro é, em grande parte, comandada pelas reações de oxidação e redução. Com efeito a forma reduzida permite a mobili zação, enquanto a forma oxidada, salvo em condições de pH muito ácí do, é sinōnimo de bloqueamento e precipitação.

A partir da equação de Nernst (Krauskopf, 15) pode-se de duzir o comportamento dos ions ferroso e férrico nas àguas. Nas rea ções de oxidação-redução do ferro a $25^{\circ} \mathrm{C}$ esta equação fica sendo:

$$
\begin{array}{ll}
E=E^{0}+0,059 \log \frac{\left(\mathrm{Fe}^{+++}\right)}{\left(\mathrm{Fe}^{++}\right)} \quad E^{0}=+0,77 \mathrm{~V} \\
E=0,77+0,059 \log \frac{\left(\mathrm{Fe}^{+++}\right)}{\left(\mathrm{Fe}^{++}\right)}
\end{array}
$$

Os potenciais de oxi-redução de ambientes são representa dos pelo simbolo Eh (15).

Em pH baixo, atē prōximo a 3 , onde o $\mathrm{Fe}^{+++} \bar{e}$ solūvel, se as concentrações de $\mathrm{Fe}^{+++}$e $\mathrm{Fe}^{++}$forem iguais, o potencial de oxi-re dução será 0,77 , variando para mais ou menos se predominar o primei ro ou o segundo termo respectivamente. Em pH neutro ou prōximo des te, o $\mathrm{Fe}^{+++}$precipita e sai do sistema de solução, tornando o ūitị mo termo da equação negativo e o Eh inferior a 0,77 se não houver outras interferências. Por isso, em meios com pH neutro e Eh supe rior a 0,77 , ē muito difícil se encontrar ferro em solução, pois o $\mathrm{Fe}^{++}$se oxidaria e precipitaria. Se, no entando, certa quantidade de $\mathrm{Fe}^{+++}$migra de um meio oxidante para um redutor recebe elétrons, se reduz em parte a $\mathrm{Fe}^{++}$, e restabelece o equilíbrio entre as formas con dizente com o Eh reinante.

Compostos presentes nas äguas naturais

As āguas naturais podem conter ferro na forma de bicarbo nato ferroso, $\mathrm{Fe}\left(\mathrm{HCO}_{3}\right)_{2}$, fluoreto férrico, $\mathrm{FeF}_{3}$, hidrōxido fērrico, $\mathrm{Fe}(\mathrm{OH})_{3}$, fosfato fërrico, alëm de cloreto ferroso, $\mathrm{FeCl}_{2}$, carbonato ferroso, $\mathrm{FeCO}_{3}$, e sulfato ferroso, $\mathrm{FeSO}_{4}$. Os dois primeiros são in completamente dissociados; o hidróxido fērrico permanece na ãgua co mo coloidal; o carbonato ferroso e o sulfato ferroso são instáveis na presença de oxigênio dissolvido, sendo prontamente convertidos em compostos fērricos. A forma mais abundante, especialmente nas àguas de fontes, ē a de bicarbonato ferroso, aparecendo as outras em pro 
porções bem menores, merecendo certo destaque, entretanto o hidróxi do férrico. As āguas de pāntanos podem ser ricas em ferro, graças aos compostos hümicos estāveis desse elemento (Rankama e Sahama, 23).

Origem do ferro ferroso nas águas

Ferro férrico pode ser solubilizado apōs a redução ao es tado ferroso. $\mathrm{H}_{2} \mathrm{~S}$, produzido durante a decomposição de compostos or gânicos contendo enxofre, é um dos mais importantes redutores encon trados na natureza e está, muitas vezes, em pequenas quantidades em soluções de intemperismo. Em adição, soluções orgânicas contendo com postos hümicos tambēm reduzem o ferro férrico a compostos solüveis. Complexos hümicos de ferro formam soluções coloidais que são está veis e consequentemente tornam o ferro apto a migrar nestaforma (23).

Para Hem e Cropper (11) "a água abaixo da superfície da terra e sem contato com o ar provavelmente tem um valor de Eh de 0,20 volts ou menos e um pH relativamente baixo (menor que 6), se su ficiente excesso de diōxido de carbono estiver presente. Sob estas condições, soluções ferrosas tão altas em ferro como 50 ppm são per manentemente estāveis.

Se esta àgua surge numa fonte e se āgua com baixo Eh ē for necida com suficiente rapidez, o nīvel de concentração de íon ferro so permanecerā alto, mesmo que o Eh na superfície possa ser conside rado acima do que os cálculos de equilíbrio indicam ser compatível com a presença de ion ferroso dissolvido".

Deposição de compostos de ferro

Quando o bicarbonato ferroso se oxida em contato com o oxi gēnio dissolvido, ocorre a seguinte reação, com a consequlente depo sição de hidrōxido férrico.

$$
4 \mathrm{Fe}\left(\mathrm{HCO}_{3}\right)_{2}+2 \mathrm{H}_{2} \mathrm{O}+\mathrm{O}_{2} \rightleftharpoons 4 \mathrm{Fe}(\mathrm{OH})_{3}+8 \mathrm{CO}_{2}
$$

Relacionado os pesos moleculares, vê-se que

$4 \times 177,886+2 \times 18,016+32,00=4 \times 106,874+8 \times 44,01$.

Note-se que esta reação requer somente uma molēcula de oxi gênio para cada 4 moléculas de hidrōxido férrico produzido, ou lg de $0_{2}$ oxida $22,24 \mathrm{~g}$ de $\mathrm{Fe}\left(\mathrm{HCO}_{3}\right)_{2}$ produzindo $13,36 \mathrm{~g}$ de $\mathrm{Fe}(\mathrm{OH})_{3}$. Cons $\underline{j}$ derando-se o teor de $\mathrm{O}_{2}$ no ar e a pressão atmosfērica verifica-se que um $\mathrm{cm}^{3}$ de ar pode provocar a precipitação de $3,5 \mathrm{mg}$ de $\mathrm{Fe}(\mathrm{OH})_{3}$. Hem (10) observou que pequenas quantidades de ar podem provocar a preci pitação de hidrōxido fērrico em amostras de āgúas naturais coletados em garrafas. Esta ocorrēncia foi tambēm observada pelo autor nos tra balhos de campo.

Hā tambēm precipitação de ferro como sulfeto em āguas es tagnadas na presença de sulfeto de hidrogênio. Por outro lado, sul fetos ferrosos podem tambēm ser oxidados (23). 
Complexos e colóides de ferro

Foi visto, nos itens anteriores, que o estado de oxidação que permite a solubilização e mobilização do ferro é o reduzido, com valência 2. Verifica-se, entretanto, que mesmo com valência 3 , como hidróxido ou outros compostos, é possível manter-se o ferro em solu ção ou ao menos em suspensão por longo tempo, graças à formação de complexos e colóides.

A importância dos complexos inorgânicos de ferro ainda não é inteiramente explorada, mas complexos com substâncias orgânicas são importantes (10). Ions com cargas opostas ou íons e moléculas pola res interagem muitas vezes um com outro muito fortemente. E esta for te interação è tratada como uma espécie dissolvida independente com sua prōpria atividade e coeficiente de atividade (Berner, 1).

0 ferro pode tambēm estar contido em colóides.

o colóide é uma suspensão de qualquer material finamente granulado (15). A eficiēncia do sol como transportador do metal de penderā de sua estabilidade, pois é obvio que um colóide que flocú le facilmente não serviria para este fim. Por exemplo, o ferro, no estado férrico, forma um hidrōxido muito insolūvel que frequentemen te permanece disperso sob a forma de um sol estável de $\mathrm{Fe}(\mathrm{OH})_{3}$. A quantidade desse sol nas correntes fluviais ê maior do que no mar, uma observação que sugere (embora não prove) que o sol é floculado ao entrar em contato com os eletrōlitos do mar (15).

Umá observação curiosa sobre a estabilidade dos colóides é o fato de um certo colóide poder ser muito estável em presença de outro, mais do que quando sozinho. Este outro ē chamado colóide pro tetor. Em geral os colöides protetores são hidröfilos. Geologicamen te, os colóides protetores têm particular importância no estudo das āguas superficiais que contêm muita matēria orgânica, pois os colói des orgânicos hidrōfilos agem como protetores de manganēs, tornañ do-os mais estāveis e, consequentemente, mais facilmente transportā veis (15).

Melfi (19) conclui que "os constituintes amorfos fērricos ou ferrissilícicos encontrados em sedimentos ou solos, são instāveis e devem ser considerados transitōrios no meio natural" e que "a priori, as condições operatōrias utilizadas em suas experiēncias de veriam facilitar a formação de ligações Si - 0 - Fe, que favoreceria o transporte do ferro complexado pela sīlica. Entretanto, exceto a reação de adsorção ocorrida na superfície do gel, nenhuma outra hou ve entre o hidrōxido de ferro e a sīlica, eliminando-se, portanto, a hipótese de a mobilidade do ferro no meio natural, encontrar-se li gada à formação de complexos ferrissilícicos pseudo-solúveis".

As partículas de $\mathrm{Fe}(\mathrm{OH})_{3}$ permanecem em suspensão por muito 
tempo, dias e atē meses, podendo ser removidas por sedimentação, por centrifugação e por filtração (11). O tamanho dessas partículas de ve ficar entre 0,5 e $4 \mu$. Hem e Cropper (11) removeram 0 hidróxido fērrico suspenso de amostras naturais e preparadas com um filtro de até 0,5 micron de diâmetro, enquanto que com outro filtro incapaz de reter partículas menores que $4 \mu$ não obtiveram o mesmo resultado.

Pode-se admitir, portanto, que é praticamente impossível - transporte de ferro atē o filtro de uma barragem passando pelo ma ciço de argila como colóide, enquanto que a forma complexada poderia permitir essa migração.

Concentrações esperadas

0 ferro estā normalmente presente em āgua inteiramente ae rada, de $\mathrm{pH}$ normal, em quantidades menores que 0,5 ppm e muitas ve zes que 0,1 ppm, provavelmente na forma fērrica. Em āguas ācidas pos suidoras de um pH inferior a 3,0, o ferro ferroso pode estar presen te em quantidades que excedem 100ppm, mas tais āguas sō são encon tradas em algumas fontes termais e em āguas de superfīcie fortemen te afetadas por despejos de esgotos contendo ācidos e ferro (10).

Sziksay (27), em levantamento das condições geoquímicas dos principais rios da Bacia do Paranā, apresenta uma tabela da compos $\underline{j}$ ção quîmica mēdia dos solutos nas àguas desses rios a qual é trans crita na Tabela I.

TABELA I. MEDIA DOS SOLUTOS NAS AGUAS DOS RIOS DA BACIA DO PARANA (B.P.) E DA AMERICA DO SUL (A.S.) EM mg/1 (SZIKSAY, 27).

\begin{tabular}{lllllllllllll}
\hline \hline & $\mathrm{Na}$ & $\mathrm{K}$ & $\mathrm{Ca}$ & $\mathrm{Mg}$ & $\mathrm{Si}$ & $\mathrm{Fe}$ & $\mathrm{Al}$ & $\mathrm{Cl}$ & $\mathrm{CO}_{3}$ & $\mathrm{SO}_{4}$ & $\mathrm{NO}_{3}$ & Total \\
\hline B.P. & 2,0 & 1,4 & 3,4 & 1,9 & 7,2 & 0,72 & 0,86 & 2,1 & 18,4 & 7,4 & 1,25 & 46,43 \\
A.S. & 4,4 & 2,0 & 7,2 & 1,5 & 5,5 & 1,4 & - & 4,9 & 15,1 & 4,8 & 0,7 & 47,1 \\
\hline
\end{tabular}

Estas āguas podem ser classificadas como carbonāticas, o que, aliās, ē mais comum em climas tropicais e subtropicais, devido à abundância de āgua de precipitação rica em ācido carbônico (27).

Ferro ferroso pode ocorrer na āgua subterrânea sujeita a ambientes redutores. Raramente concentrações acima de $50 \mathrm{mg} / 1$ podem ocorrer em äguas com pH de 5 a 8 . Concentrações acima de $10 \mathrm{mg} / 1$ são comuns (10).

0 ferro, nas amostras de āgua subterrānea, geralmente não estā em equilíbrio. A precipitação do hidrōxido férrico não alcança o nivel previsto pelo produto de solubilidade, e a reação entre o ion ferroso e o oxigēnio não dispõe de tempo suficiente para estabe lecer concentrações entre os íons férrico e ferroso (11).

Hem e Cropper (11), analisando uma fonte, verificaram que 
as condições de $\mathrm{pH}$ e Eh, combinadas com a solubilidade, não justifi cavam o teor de ferro encontrado. Concluiram, então, que nestas con dições o ferro ferroso era instāvel. No aqüīfero devia ser estāvel enquanto que na fonte, devido ao suprimento rāpido, conseguia man ter-se em solução. 0 pH medido corresponderia ao real devido ao efei to tampão do $\mathrm{HCO}_{3}^{-}$. Portanto o Eh medido não corresponderia às condi ções de equilíbrio do aqüífero.

Foram vistas atē aqui as condições quĩmicas de solubiliza ção e precipitação do ferro, bem como as formas pelas quais pode ocor rer nas äguas naturais e suas concentrações ambientais. Resta ver se as condições reinantes numa barragem são favorāveis à solubilização do ferro, transporte atravēs do nūcleo e posterior precipitação no filtro.

CONSIDERAÇOES SOBRE O AMBIENTE LACUSTRE

Estratificação térmica

0 reservatōrio de uma barragem è um lago artificial e, por isso convēm fazer um estudo sobre as condições geoquímicas em ambien tes lacustres.

Em todos os lagos de suficiente profundidade, a āgua ten de a se dividir em uma região superior de temperatura mais ou menos uniforme, com circulação e certa turbulência, denominada epilîmnio, e outra região profunda, fria e relativamente não perturbada denomi nada hipolïmnio. Estas definições são atribuidas a Birge em 1910. (in 12). A região de rápida queda na temperatura separando o epilīmnio do hipolímnio foi denominada de "sprungschicht" por Richter em 1892, de "Thermocline" por Birge em 1897 e de camada de descontinuidade por Wedderburn em 1907. Termoclínio é o termo mais usado atualmente e de ve ser redefinido como o plano de mäxima taxa de decréscimo de tem peratura (Hutchinson, 12).

A circulação da āgua nos lagos é devida ao vento. Uma vez estratificada termicamente, a ăgua do epilmnio resiste a ser empur rada para dentro do hipolímnio pois este possui uma densidade maior em função da temperatura mais baixa.

Com relação aos modelos de estratificação hã dois tipos de lagos, os dimícticos e os monomícticos. Os primeiros ocorrem nas re giões temperadas onde a temperatura cai abaixo de $4^{\circ} \mathrm{C}$ e durante 0 outono, o epilímnio ē resfriado atē atingir a temperatura do hipo límnio. Nestas ocasiões o lago inteiro entra em circulação, chegan do a āgua proveniente da superfīcie atē as profundidades. Este fenō meno de circulação total ē destacada por Twenhofel (28), Krumbein e Sloss (16) e Bradley (2) para explicar o regime químico do hipolîmnio. Durante o inverno ocorre uma estratificação inversa ficando a āgua mais fria e abaixo de $4^{\circ} \mathrm{C}$ no epilîmnio. Durante a primavera ocorre 
outra circulação devido ao aquecimento da superfície (2).

Nas regiões sub-tropicais, onde a temperatura da água não cai abaixo de $4^{\circ} \mathrm{C}$, hā geralmente apenas uma circulação durante o in verno, quando então a temperatura do epilímnio se iguala a do hipo 1 ỉmnio e por isso são chamados de monomícticos. Em invernos menos ri gorosos o resfriamento da superfïcie pode não ser suficiente para causar uma circulação atē o fundo do lago (12). A estratificação ter mal é aỉ mais durāvel e mais estāvel que nos lagos temperados, por que a āgua superficial aquecida è muito menos densa que aquela do hipolímnio, embora a diferença de temperatura não seja grande. Acon tece que na faixa dos $20^{\circ} \mathrm{C}$ a diminuição da densidade com o aumento de temperatura $\bar{e}$ mais acentuada que em faixas mais baixas (2).

Nas regiões equatoriais, onde não existem estações de tem peraturas definidas, os lagos tornam-se estratificados, mas podem ter sua āgua revolvida toda a vez que a temperatura permanecer uns poucos graús abaixo do normal, por vārios dias (2).

As figuras 1 e 2 mostram perfis de lagos brasileiros extrai dos de Kleerekoper (14).

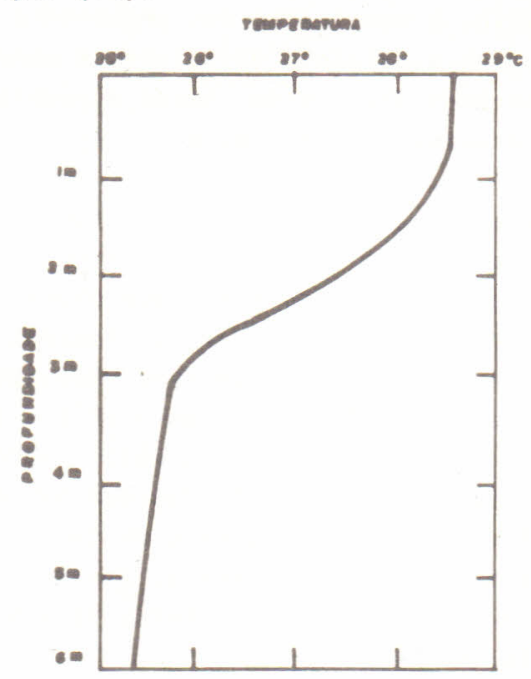

Figura 1. Termoclīnio no açüde Bodocongo, Campina Grande, Paraỉba, em 12/4/1943, segundo dados de Stil1man Wrigt (K1eerekoper, 14).

Condigões geoquimicas

As condições do epilímnio dos lagos temperados e tropicais são favorāveis ao máximo desenvolvimento da vida e da oxidação.

Há abundância de oxigênio para os animais e diōxido de car bono adequado para as plantas. 0 hipolỉmnio de pequenos lagos comu 


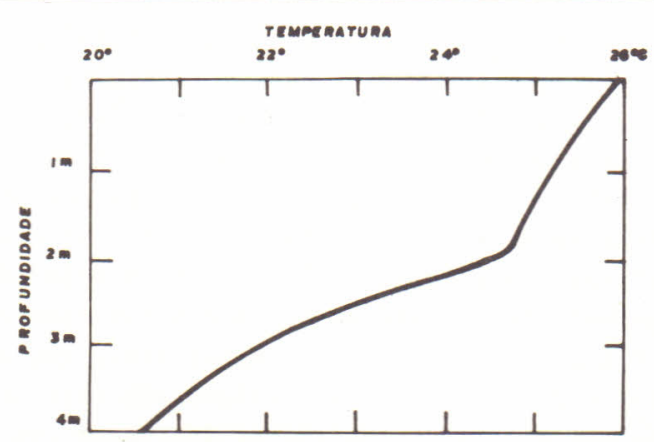

Figura 2. Termoclínio na represa de Santo Amaro, São Paulo, na esta ção G, em 01/12/1937 (K1eerekoper, 24).

mente tem água com maior teor de dióxido de carbono, menor teor de oxigênio e pH mais baixo que o epilimnio. Estas condições favorecem a redução pela matéria orgânica, a solução dos carbonatos e a escas sez de vida (28).

No hipolímnio, a respiração dos organismos e a degradação da matēria orgânica usam o oxigênio dissolvido e aumentam a quanti dade de dióxido de carbono dissolvido. Sendo consumido todo o oxigê nio a āgua torna-se progressivamente mais carregada com sulfeto de hidrogènio (2).

Não hā dūvida de que o dēficit de oxigênio no hipolīmnio é devido à oxidação da matéria orgânica que entra no lago em suspen são ou em solução. O oxigēnio dissolvido pode diminuir no hipolímnio ou por consumo na interface lama-água ou por comsumo na água livre.

0 consumo de oxigênio na interface lama-āgua foi constata do por vārios pesquisadores. Alsterberg em 1922 (in 12) verificou a formação de uma microzona com perda de oxigēnio sobre a lama dos la gos. Lonnerblad, em 1930 (in 12), verificou que sobre a lama de la gos produtivos mas transparentes o consumo de oxigênio poderia ser abolido colocando-se bactericida na lama e, noutro experimento com sedimentos turfosos de lagos húmicos marrons, determinou um consumo de oxigênio puramente quîmico.

A formação dessa microzona pela respiração microbiana foi também considerada por Grote em 1934 (in 12), que calculou a profun didade, na qual o oxigênio desaparece inteiramente. Admitindo uma taxa muito razoável de $400 \mathrm{~cm}^{3}$ de $0_{2} / \mathrm{cm}^{3}$. dia para taxa de respira ção das bactērias por unidade de volume na lama, a concentração de oxigênio será reduzida de $11,5 \mathrm{mg} / 1$ na superfície da lama para zero em $2 \mathrm{~cm}$ de profundidade.

Para manter este estado contínuo $9,2 \mathrm{mg}$ de $\mathrm{O}_{2} / \mathrm{cm}^{2}$. dia de 
vem passar da āgua para a lama. Enquanto o lago estiver em plena cir culação isto é possível, mas tão logo a ăgua se torne relativamente estagnada, formar-se-ā uma microzona de desoxigenação (12). Esta mi crozona influencia o resto do hipolímnio.

0 potencial redox de sedimentos lacustres geralmente está em torno de 0,0 volt e, portanto, com exceção de casos especiais, pos sui propriedades redutoras. Alguns valores medidos por Kusnetzow, em lagos prōximos a Moscou, dão valores de $E h=-0,122$ atē $E h=+0,058$ (12). Outros valores para lagos de Wisconsin variam de Eh $=-0,140$ até $E h=+0,200$. Mas em vista da natureza complexa das mudanças ver ticais prōximo à superfície da lama, estas variações tem pouco signi ficado. Mortimer (in 12) instalou duas estações para medida ao 1on go do tempo tendo constatado em ambas que a vārias profundidades a baixo de $4 \mathrm{~cm}$ da interface lama-ägua o Eh permanece em valores cer ca de 0,0 volt.

o ferro ē praticamente insolūvel na forma iônica nos valo res normais de $\mathrm{pH}$ e potencial redox encontrados nas águas do ep límnio dos lagos.

A distribuição vertical do ferro reflete a distribuição vertical do potencial redox.

Sempre que uma microzona de dēficit de oxigênio for bem desenvolvida e a superfície da lama estiver no estado reduzido, 0 ferro ferroso tende a se difundir para a āgua livre. Se as camadas mais baixas estiverem ainda recebendo alguma quantidade apreciāvel de oxigēnio, o hidnōxido férrico pode se formar e permanecer por a 1 gum tempo nas āguas profundas. Quando as āguas inferiores forem es sencialmente livres de oxigênio, considerāveis quantidades de ferro ferroso usualmente se acumulam nas äguas profundas do hipolímnio.

\section{BIOGEOQUIMICA APLICADA AO FERRO}

\section{Generalidades}

Os seres vivos que participam de processos biogeoquímicos de importância são as bactērias, fungos, algas e protozoārios.

As pesquisas em biogeoquỉmica geralmente têm se dirigido para o aproveitamento de minerais de baixo teor, tanto no exterior (Kuznetzov, 17; Goñi, 4), como no Brasil (Vaisbich, Pintoe Borzani, 30), onde está se estudando o processo de biolixiviação.

Muitos desses estudos e conclusões partem de meios de cul tura altamente favorāveis ao desenvolvimento de microorganismos. Mes sineva (20) observou uma grande discrepāncia entre o nūmero e taxa. de desenvolvimento de bactērias nas culturas e nos meios naturais. Nestes, as cēlulas se dividem uma vez cada duas semanas. A morte das bactērias tem a mesma taxa que sua multiplicação, pois a biomas sa permanece a mesma. 
Tomando-se um grupo de parāmetros selecionados, verifica-se que os micróbios crescem dentro de certos níveis máximo e mīnimo. A faixa sobre a qual ocorre o crescimento, forma o contínuo biológico (Zajic, 32). Esses níveis são: $-20^{\circ} \mathrm{C}$ e $104{ }^{\circ} \mathrm{C}$ de temperatura; $-450 \mathrm{mV}$ e + $850 \mathrm{mV}$ para $0 \mathrm{Eh} ; 1$ a 10,1 para 0 pH; $70 \mu \mathrm{g}$ de matēria orgānica por litro de āgua (āgua destilada) e 4,1 $\mathrm{M}_{\text {de }} \mathrm{MgSO}_{4}$ (quase $50 \%$ de sal para a salinidade); 0,1 a 1000 atm de pressão; existência de àgua. A dependência da água pelos micrōbios neste planeta deve estar diretamente ligada à sua abundância (32).

As bactērias que aparecem na āgua subterrânea a milhares de metros de profundidade podem ter a mesma idade que os sedimentos ou provir de infiltração a partir da superfície atual. Quase todas as āguas subterrāneas na biosfera sofreram uma alteração singenēti ca em sua composição quĩmica, em algum grau e a vārios estāgios em sua histōria geolōgica. O fator essencial mas inadequadamente estu dado é a transformação biogênica, isto è, mudanças na composição iô nica e gasosa atravēs da atividade dos microorganismos (Gurevich, 8).

E forçoso constatar que as tentativas de explicação por via puramente química, de processos onde intervēm o ferro e o manganês na biosfera, são pouco convincentes. Assim observa-se os ciclos des ses elementos sob um prisma biōtico. Foi o que fizeram C.G.Ehrenberg, M.S. Vinogradsky, G. Bertrand, respectivamente em 1836, 1883 e 1905 (in 5).

Processos

Os processos pelos quais os microorganismos modificam os minerais foram resumidos por silverman e Ehrlich (26) em enzímicos e não enzímicos.

Dentre os processos enzímicos há as reações redox repre sentadas por transformações minerais em grande escala causadas por oxidações ou reduções enzímicas diretas. Processos autotróficos qui miossintēticos oxidam os minerais para obter tanto a energia como o poder de redução requerido para a assimilação do $\mathrm{CO}_{2}$. Autotrōficos fotossintēticos assimilam $\mathrm{CO}_{2}$ com a ajuda da energia da luz solar, sendo o poder redutor necessărio fornecido pela oxidação dos mine rais. A redução de minerais por certos heterotröficos fornece o po der de oxidação requerido para a oxidação anaerōbia de nutriente or gānico e a produção de energia usua 1. Por causa da magnitude das exi gēncias relativas à energia e poder de redução ou oxidação desses or ganismos, grande quantidade de minerais precisa ser transformada (26).

A digestão de complexos metālicos, outro processo enzīmi co, atinge alguns íons inorgânicos em solução aquosa, particularmen te ĩons de ferro, cobre, manganês, zinco, cālcio e magnésio que for mam quelatos ou complexos com certos compostos quỉmicos orgânicos e 
outros (26). Muitas bactērias heterotrōficas e fungos são capazes de usar um ou outro dos agentes complexantes orgānicos como carbono, nitrogēnio, ou outra fonte de energia, e com isso libertam o ion inorgânico complexado. Os ions liberados precipitam como hidrōxidos insolūveis, óxidos ou sais, devido a reações expontāneas como a água ou outras substâncias dissolvidas, a um pH e Eh apropriado (26).

Agentes complexantes podem também auxiliar a dissolver substâncias inorgânicas parcamente solúveis, complexando um ou mais produtos da dissociação, mudando assim o equilîbrio químico em fá vor da solução. Agentes complexantes formados por micróbios podem, assim, levar à solubilização de minerais (26).

Dentre os processos não enzimāticos hā a função dos produ tos metabólicos. Transformações minerais podem ser efetuadas pela interação com os produtos finais do metabolismo. Microorganismos he terotrōficos podem formar ācidos inorgānicos, tais como $\mathrm{H}_{2} \mathrm{~S}_{2} \mathrm{H}_{2} \mathrm{CO}_{3}$, $\mathrm{HNO}_{3}$, ou $\mathrm{H}_{2} \mathrm{SO}_{4}$, ācidos orgānicos, amōnio, bases orgānicas eĩons inor gânicos, como sulfeto, sulfato, carbonato, fosfato e fosfito. Todas estas substâncias podem reagir não biologicamente com a matēria inor gânica dissolvida ou sōlida. Os ácidos inorgânicos e orgânicos podem dissolver minerais insolúveis, tais como, calcārio, gipsita, anidri ta, silicatos e outros (26).

Adsorção na superfĩcie das células é outro mecanismo não enzimático envolvendo microorganismos e que pode reagir extensiva mente com o ambiente mineral. Consiste na adsorção da matéria mine ral à superfície da cêlula. Esta é considerada uma importante função das bactērias embainhadas (clamidobactērias) e certos flagelos. Su põe-se que a composição quỉmica destas cēlulas tenha uma afinidade singular para o ferro e manganēs, os quais se fixam à superfīcie da cēlula na forma de hidrōxidos e sais. De fato, as bainhas de algumas dessas bactērias foram descritas como consistindo de $\mathrm{Fe}(\mathrm{OH})_{3}$ e $\overline{0} x \underline{j}$ dos inorgānicos. Sabe-se que os óxidos de ferro e manganēs são bons adsorventes eles mesmos, ōxidos de ferro para substâncias aniô nicas e ōxido de manganês para substâncias catioñicas, e que parte do processo de adsorção provavelmente não é atribuível à superfície da cēlula propriamente mas à precipitação inorgânica sobre ela. En tretanto, ē interessante notar que são descritos organismos que acu mulam ferro preferencialmente. Tem sido reivindicado, entretanto, que a acumulação de ferro e manganês nas bainhas ou caules de algumas bactērias corresponde ao estabelecimento do produto final da oxida ção enzỉmica do ferro e manganês, particularmente no caso da Gallio nela (26).

Reducão do ferro por ação de microorganismos

Para Silverman e Ehrlich (26) a redução enzỉmica do îon 
férrico para ion ferroso não tem sido inequivocamente demonstrada, embora evidências muito sugestivas de tais atividades tenham sido publicadas.

A redução do ferro foi observada em certo número de solos, favorecida pelo baixo pH e sendo mais comum onde há suficiente maté ria orgânica (32). Kalakutskii (in 32) isolou uma cultura de pseudo monas de um solo gley-podzólịco que produziu 10 a $15 \mathrm{~g}$ de $\mathrm{Fe}^{++}$por litro, sob condições anaeröbicas.

Muitos pesquisadores observaram que öxidos de ferro e de manganēs são usualmente destruĩdos pela redução microbiana para fer ro ferroso e manganēs manganoso (32). Organismos específicos que se tēm mostrado ativos na redução do ferro e do manganēs incluem mem bros do grupo Bacizlus macerans polymixa e Thiobacillus thiooxidans. Outros organismos, no entanto, devem estar tambēm envolvidos (32).

Atravēs de uma ação indireta, ou não enzimātica os microor ganismos podem produzir um ambiente redutor pela formação de produ tos finais metabōlicos que podem agir como redutores do ferro e do manganês. Desta forma, as bactērias sulfato-redutoras tomam importân cia na biogeoquímica do ferro. As importantes são: Desulfovibrio desulfuricans, Desulfovibrio aestuarii, Desulfovibrio rebentschikii, Desulfovibrio orientis, Clostridium nigrificans (32).

Os sulfatos redutores utilizam sulfato como oxidante para numerosos substratos orgânicos, em adição ao hidrogênio. Os materiais orgânicos que provêem energia para a redução do sulfato não foram enumerados em detalhe. Acidos orgânicos e carbohidratos são utiliza dos rapidamente (32).

Para o desenvolvimento de bactērias redutoras ē necessārio um ambiente anaeróbico com hidrogēnio e suprimento adequado de maté ria orgânica. Normalmente estes micrōbios toleram alta acidez, con dições halofïlicas, altas concentrações de sulfetos e nĩveis tōxi cos de metais. Quase todas as formas de matēria orgānica proporció nam o crescimento de um ou mais micrōbios que caem neste grupo, por exemplo, celulose, lignina, despejos de esgotos, etc. Estes micróbios são bons limpadores dos produtos de despejos orgânicos de fontes na turais ou industriais (32).

0 ambiente sulfato redutor deve ter um Eh de 600 a $-400 \mathrm{mV}$. Os micróbios sulfato-redutores crescem sobre uma grande faixa de aci dez e alcalinidade, embora as condições neutra ou levemente alcali na sejam preferidas (Bass-Becking et alii, in 32).

0 crescimento de redutores de sulfato nas àguas de sub-su perfície é favorecido pela baixa mineralização (Dostalek e Kvet, in 32 ). 
Solubilizacão do ferro contido em rocha sob influencia de microorganismos

Ribeiro, Santos e Martelli (24) fizeram um ataque experi mental sobre um diabásico com um líquido onde havia cultura de um fungo, Aspergizzus niger, extraído do solo. Apōs 25 dias, o conteū do de ferro das soluções com fungo era 26 vezes maior do que nas so luções estēreis. A solubilidade do ferro nesses minerais dependeu de sua natureza, da superfície de ataque e da concentração dos produtos metabólicos. Concluiram, ainda, que a ação do fungo sobre a rocha não é direta, mas resulta dos produtos do metabolismo e que o ferro iônico liberado dos minerais forma, com os produtos metabólicos do fungo, um complexo organo-metālico.

oxidação e deposigão do ferro por acão de microorganismos

Harder (9) fez extenso estudo sobre depósitos sedimentares de ferro do mundo e desenvolveu uma sērie de experiências em labora tōnio onde verificou que, nas soluções inoculadas com bactērias, ha via precipitações de ferro, enquanto que nas esterilizada não ocor ria o mesmo.

A formação geoquímica de depōsitos sedimentares e autigê nicos tem sido definida por vārios autores. A base para essa defesa assenta em parte no achado de bactērias fósseis ou vivas ou algas nos depósitos de ferro e de manganēs e, em parte, nas demonstrações de laboratōrio segundo as quais tais organismos podem causar a for mação de ōxidos de ferro e de manganês. Os tipos de minerais de óxí dos de ferro e de manganês com os quais os microorganismos estão as sociados incluem limonita, goethita, $-\mathrm{MnO}_{2}$ e ōxido de manganês amor fo (26). Os micrōbios catalizam a oxidação e a redução do ferro atra vēs de todos seus estados de valência importantes (32).

$$
\mathrm{Fe}_{\left(\mathrm{O}_{2}\right)}^{\rightleftharpoons} \mathrm{Fe}^{++}+2 \mathrm{e}_{\left(\mathrm{O}_{2}\right)}^{\rightleftharpoons} \mathrm{Fe}^{+++}+\mathrm{e}^{-}
$$

Por ação indireta ou não enzimātica, alguns microorganis mos podem oxidar os compostos de ferro e de manganês, causando a pre cipitação desses elementos pela geração de um ambiente oxidante,atra vēs da geração de $\mathrm{O}_{2}$ ou consumo de $\mathrm{CO}_{2}$ (função dos produtos metabō licos). Algumas algas, Cyanophýcecie, Chrysophyceae, volvocales, Chlorococcales, Eugleneae, Conjugales, Ulotricales, são particular mente ativas desta maneira, precipitando óxidos de ferro e manganēs, que podem incrustar a superfície das cēlulas. Por outro lado, os mi crōbios podem simplesmente acumular ferro e manganēs jā oxidados. A adsorção de ōxidos de ferro e de manganês prē-formados pode ser de vida a uma capacidade especial de ligação para esses compostos. Acha-se que muitas das bactērias laminadas (Crenothrix, Clonothrix, Lepto thrix), uma das bactērias com caule (Gallionella), e alguns protozoā 
rios flagelados (Anthophysa, Siderodendron, Bikosoeca, Siphomonas) funcionem desta maneira, embora elas possam tambëm participar na for mação destes ōxidos (26).

Em ação direta ou enzimātica, os microorganismos podem in teragir enzimaticamente com compostos de ferro e de manganês. Por exemplo, os Thiobacizli ferro oxidantes oxidam o ferro ferroso para ferro fērrico sob pH ācido, onde a autooxidação do ferro ē extrema mente vagarosa. Gazzionezza pode oxidar o ferro enzimaticamente sob pH neutro, onde a autooxidação é rāpida e difîcil de distinguir de uma oxidação biolōgica. A prova da oxidação do ferro pela Gazzionezza repousa sobre a observação do seu crescimento na ausência de carbo no orgânico, onde o ferro ē a ūnica fonte de energia possível para o crescimento. Leptoyhrix ochracea pode também oxidar o ferro na au sência de uma fonte de carbono orgânico; isto é descrito como uma au totrofia facultativa (26).

A interação enzimātica com compostos de ferro e de manga nês pode se manifestar tambēm atravēs de digestão de complexos con tendo ferro ou manganès.

A eficiência na oxidação do ferro e fixação do $\mathrm{CO}_{2}$ depen de tambēm das condições fisiolōgicas da cultura, decaindo em cultú ras velhas.

As deposições ferruginosas em poços de exploração de água subterrânea, por influência de bactērias, são bastante conhecidas. Apenas como exemplo citam-se casos relatados por Brown (3) e Grime (6).

0 primeiro autor verificou que de 19 poços na Califörnia, 9 estavam afetados por organismos da famīlia dos ferro bactērias. 0 crescimento destas bactērias em grande quantidades é manifestado pe la turbidez nos sistemas de distribuição e nos reservatōrios, por massas floculentas que aderem às paredes e flutuam na água.

o segundo relata a obstrução de um poço profundo em Washington. Devido a uma ēpoca de retirada intensa, o nĩvel dinâmi co baixou a uma cota inferior à da bomba, provocando assim um bom beamento de ar e forte aeração da āgua. No tanque formou-se uma plä ca de mais ou menos $7,5 \mathrm{~cm}$ avermelhada. A anālise deste material mos trou 450.000 bactērias por $\mathrm{ml}$. Relata ainda o caso de outro poço que teve seu filtro obstruído por bactērias sulfato redutoras, ferro-bac tērias, como Crenothrix, e algas.

DEPOSIÇAOO DO FERRO EM CAMADAS ARENOSAS

Se existem condições químicas para deposição de hidróxido fērrico na natureza, devem ocorrer camadas arenosas cimentadas com essa substância. 
Todos os processos discutidos anteriormente citam reações num meio liquido, acima dos sedimentos. Pouco existe sobre a prec $i$ pitação de compostos fërricos nos poros das rochas. Berner (1) expli ca a difusão dentro dos sedimentos recobertos por āgua, devido à existência de gradientes quỉmicos verticais, especialmente em sedi mento anaeróbio cuja āgua dos poros seja alta em $\mathrm{Mn}^{++}$ou $\mathrm{Fe}^{++}$, reco berto por ägua aerada livre de $\mathrm{Mn}^{++}$ou $\mathrm{Fe}^{++}$Estes ĩons, devido aque le gradiente, ascenderiam por difusão e precipitariam na interface solo-āgua.

Persons (22) explica a formação de "lateritas sedimenta res" pela deposição ou cimentação de areia situada sobre substrato impermeāvel, situando os elementos alimentadores dessa deposição, tais como sais de ferro e aluminnio, acima dessa interface. Com a introdu ção de sais em solução, nesta situação, formar-se-iam concreções ao redor de determinados grãos de areia e, pelo crescimento destas, uma camada fina e dura na interface com o estrato impermeāvel subjacen te deixando, freqüentemente, interstícios de areia não cimentada.

Suguio e Barbour (25) descreveram as crostas limoniticas existentes na Bacia de São Paulo e encontraram esses materiais não sō na situação mencionada acima, mas tambēm em camadas arenosas, 10 go abaixo de outras argilosas, e em outras diversas posições dentro das camadas. Admitem como fatores bāsicos, as diferenças de permea bilidade e "controles ditados pelos equilíbrios físico-químicos (con ceńtração, Eh, pH, etc) das soluções que transportam o ferro". As espessuras destas crostas são, em geral, de 10 a $20 \mathrm{~cm}$, podendo che gar at $\overline{\mathrm{e}} 1 \mathrm{~m}$.

Willig e Formoso (31) estudando a gênese das couraças de ferro da formação Rio Bonito, no Rio Grande do Sul, descrevem a exis tência de cimentação ferruginosa, de maior intensidade no topo das camadas arenosas daquela formação, numa espessura menor que $50 \mathrm{~cm}$ observando, ainda, que as partes mais permeāveis apresentam maior es pessura. Essas camadas estão situadas imediatamente abaixo de outra argilosa da formação Palermo. A origem dessas crostas é interpreta da como resultado de um processo em que a āgua satura os solos deri vados da formação Palermo por serem argilosos e pouco permeāveis, car rega-se de ions ferrosos, devido ao ambiente redutor desses solos, depois cai nas camadas arenosas, permeāveis e aeradas da Formação Rio Bonito. Nelas o ferro se oxida e precipita como hidrōxido férrico.

\section{CONCLUSÕS}

Atravēs desta revisão bibliogrāfica è possível estabelecer uma teoria sobre o processo de obstrução do filtro de uma barragem de terra e, assim, explicar os casos mencionados na introdução.

Uma barragem barrando um rio, cria um ambiente de āguas qua 
se paradas que se comportam como num lago. Esse lago artificial deve desenvolver um hipolímnio, o qual teria um ambiente redutor.

As ăguas do hipolímnio podem conter ferro dissolvido pro veniente ou dos rios ou da lama do fundo. Confirmando a primeira ori gem, existem os dados sobre o conteüdo de ferro em rios da Bacia do Paraná que embora em pequena percentagem podem representar acumula ção considerāvel apōs um período suficiente de tempo. Esse ferro flu vial pode estar sob a forma férrica, em partīculas muito finas em suspensão, ou sob a forma de complexos. Na primeira seria incapaz de atravessar o maciço argiloso com poros muito finos (Veja-se a expe riência de Hem e Cropper, (11). Mas tanto numa como em outra forma pode se reduzir ao entrar no hipolimnio e encontrar condições do pH e Eh favorāveis conforme foi visto da förmula de Nernst. Passando ao estado reduzido, esse ferro entra em solução verdadeira e pode atravessar o maciço de terra. A outra origem do ferro no hipolímnio é explicada pela difusão dos ions ferrosos que se formam na lama do fundo. Nesta, com certa acumulação de matēria orgânica, desenvolve-se - ambiente favorável às bactērias redutoras, especialmente as redu toras de sulfatos, propiciando todos os processos biogeoquímicos de redução do ferro.

Foi visto ainda, no ambiente lacustre, que a poucos centí metros abaixo da superfície da lama, o Eh chega a zero. Essa lama existe tanto abaixo do hipotimnio quando do epilimnio, esperando-se que abaixo daquele seja mais redutora do que abaixo deste. A āgua do reservatōrio, ao penetrar no maciço de terra, tem de atravessar necessariamente aquela lama, levando consigo tanto o ferro dissolvi do como os produtos metabōlicos ou ions que poderão reduzir o ferro contido no solo do maciço de terra.

Tudo isto faz supor que a āgua que percola na maciço de terra, principalmente em sua parte inferior, está num estado reduzi do e carrega-se gradativamente de ferro.

Se a primeira parte do processo foi a redução e solubili zação, a segunda serā de oxidação e precipitação, identificando - se o oxigēnio do ar como principal oxidante. Esta deposição poderá ocor rer ou sobre a faixa de capilaridade, ou no filtro, ou na saída dos drenos e à jusante da barragem.

Se houve oxidação e precipitação dentro do maciço de ter ra esse fato não terā nenhuma importāncia prātica, o mesmo ocorren do se essa reação se der na saīda dos drenos, parte fácil de ser limpa, e nas àguas de jusante, ao menos para o funcionamento da bar ragem. Todo o problema se concentra na precipitação dentro do fil tro, o qual possui difícil acesso e se constitui elemento essencial da barragem. 0 inĩcio da oxidação no filtro ainda não constituiria 
problema desde que houvesse suficiente fluxo para impedir a precipi tação, como foi visto no caso de fontes de água subterrānea em equi lî̉brio instāveis.

Pelo estudo em camadas naturais, foi visto que as cimenta ções ferruginosas podem situar-se na base de camadas arenosas, por descida de material cimentante (Persons, 22); no topo, devido à su bida e posterior oxidação dos ĩons (Berner, 1) ou devido à descida de soluções provenientes de camada superior menos permeável e pos terior oxidação abaixo da interface (Willig e Formoso, 30).

Admite-se que a migração do ferro se processe sob a forma de bicarbonato ferroso, uma vez que $\mathrm{O}_{\mathrm{HCO}_{3}^{-}} \mathrm{e}$ o ânion mais comum, e precipite sob a forma de hidróxido férrico quando encontra ambiente oxidante, sendo essa reação auxiliada ou não por bactērias. As cros tas que se formassem no filtro poderiam tomar qualquer uma das posi ções mencionadas acima, embora a explicação mais adaptada pareça ser a de Willig e Formoso (30).

\section{REFERENCIAS BIBLIOGRAFICAS}

1. BERnER, R.A. Principles of chemical sedimentology. New York, Mc Graw-Hill, 1971. 240 p.

2. BRADLEY, W.H. Limnology and the eocene lakes of the Rocky Mountain region. Bulletin of the Geological Society of America, Boulder, $69: 635-48,1948$.

3. BROWN, K.W. The occurrence and control of iron bacteria in water supplies. Journal of America Water Works Association. New York, $10(11): 1648-1700,1934$

4. Goll, J. Aperçu sur les études porsuivies au B.R.G.M. em micro biologie. Bulletin du Bureau de Recherches Geologiques et Minieres, Orlēans, (1):27-9, 1973. Deuxième série. Section IV.

5. GoNI; J. et alii. La géomicrobiologie et la biominéralurgie. Buz letin de la Sociéte Franģaise de Minéralogie et de Cristalo graphie, (96):252-66, 1973.

6. GRIME, E.M. Problems with iron in deep well supplies. Journal of American Water Works Association, New York, 37:1173-7, 1945.

7. GUERRA, M.0. Ação quîmica e biológica na colmatação de filtros e drenos implicações no comportamento da barragem do Rio Gran de. In: SEMINARIO NACIONAL DE GRANDES BARRAGENS, 13, Rio de Janeiro, 1980. Anais ... Rio de Janeiro, Comitê Brasileiro de Grandes Barragens, 1980. p. 257-89.

8. GUREVICH, The role of microorganisms in producing the chemical composition of ground water. In: Geological activity of microor ganisms. New York, Institute of Microbiology, 1961, p.65-75.

9. HARDER, E.C. Iron-depositing bacteria and their geologic relations. 
Professional Paper, Washington, (113):1-89, 1919.

10. HEM, J.D. Study and interpretation of the chemical characteristics of natura1 water. Water-Supply Paper, Washington (1473):11-363. 1979.

11. HEM, J.D. \& CROPPER, W.H. Survey of ferrous-ferric chemical equilibria and a redox potentials. Water-Supply Paper. Washington (1459A): 1-31, 1959.

12. HUTCHINSON, G.E. A Treatise on Limnology. Geography physics and chemistry. New York, John Wiley \& Sons, 1957. V.1. 1015 p.

13. INFANTI, Jr, N.R. \& KANJI, M.A. Preliminary considerations on geochemical factors affecting the safety of earth dams. In: INTERNATIONAL CONGRESS OF THE INTERNATIONAL ASSOCIATION OF ENGENEERING GEOLOGY, 2, São Paulo, 1974. Proceedings... São Paulo, International Association of Engineering Geology, 1974. Tema 4, p.33, 1-11.

14. KLEERECOPER, H. Introdução ao estudo da Zimnologia. Rio de Ja neiro, Ministērio da Agricultura - Departamento Nacional de Produção Anima 1, 1944. 329 p. (Série Didātica, 4).

15. KRAUSKOPF, K.B. Introducão à geoquimica. São Paulo Universidade de São Paulo, 1972. V. 1, 294 p.

16. KRUMBEIN, W.C. \& SLOSS, L.L. Sedimentary enrironments. In:-Stra tigraphy and sedimentation. San Francisco, W.H. Freeman,1959 p. 186-223.

17. KUZNETSOV, S.I. Principal trends in the investigation of geolo gical activity of microorganisms. In: Geological activity of microorganisms. New York, Institute of Microbiology, 1961,p.1-5.

18. MACIEL FILHo, C.L. Estudo do processo geoquimico de obstrucão de filtro de barragens. São Paulo, Universidade de São Paulo. Instituto de Geociēncias, 1982. 136 p. Tese de Doutoramento.

19. MELFI, A.J. Influência da silica na evolucão dos geles amorfos de ferro (III): estudo experimental simulando condições tro picais úmidas e bem drenadas. São Paulo, Instituto de Geo ciências e Astronomia da USP, 1971. Tese de Livre Docência em Geologia.

20. MESSINEVA, M.A. The geological activity of bacteria and its effects on geochemical process. In: Geologic activity of microorganisms. New York, Institute of Microbiology, 1961 p. 6-14.

21. OLIVEIRA, H.G. \& CAMARGO, W.M. Observação do desempenho e recu peração de barragens obras anexas e reservatōrios. In: SEMI NARIO NACIONAL DE GRANDES BARRAGENS, 11. Fortaleza. Anais... Fortaleza, Comitê Brasileiro de Grandes Barragens, 1976. T吕 ma $3, \mathrm{p} 18-20$.

22. PERSONS, B.S. Laterite genesis Zocation use. New York, Plenum, 1970. $103 \mathrm{p}$. 
23. RANKANA, F. \& SAHAMA, T.G. Geochemistry. Chicago, The University of Chicago, 1950, $912 \mathrm{p}$.

24. RIBEIRO, R.M.; SANTOS, A.M.; MARTELLI, H.L. Alterações microbią nas em rochas: solubilização do ferro por ação de fungos em diabāsios. Revista Brasileira de Geociências. São Paulo, 6:146 $-55,1976$.

25. SUGUIO, K \& BARBOUR, A.P. Morfologia e gênese das estruturas $1 \underline{i}$ monîticas dos sedimentos da bacia de São Paulo. Anais da Academia Brasizeira de Ciêneias. São Paulo, 41(2): p.161-80, 1969.

26. SILVERMAN, M.P. \& EHRLICH, H.L. Microbial formation and degration of minerals. Advances in Applied Microbiology, New York, 6 : $153-206,1964$.

27. SZIKSZAY, M. Dados hidrogeoquímicos de rios da bacia de Paranā. São Paulo, Instituto de Geociēncias da USP, 1973. Separata do Boletim IG, São Paulo, 4:97-108, 1973.

28. TWENHOFEL, W.H. Classification of environments. In:- Principles of sedimentation. New York, MC Graw-Hi11, 1939.

29. VACHAUD, G. Transferts hydriques entre sol et atmosphere. COUR DE IIIO CYCLE DES UNIVERSITES ROMANDES, Neuchate1, 1976. Ré sumé de séminaire. Neuchatel, Universite Scientifique et Me dicale de Grenoble, 1976. p. 1-28. Section Sciences de la Terre.

30. VAISBICH, S.; PINTO, M.L.M. ; BORZANI, W. Lixiviação bacteriana de rejeito de minērio de cobre de Camaquã pela ação bacteria na isolada do prōprio rejeito. Revista Brasizeira de Tecnozo gia. São Pau1o, 10:289-302, 1979.

31. WILLIG, D.D. \& FORMOSO, M.L.L. Estudo geoquímico e gênese das couraças de ferro da formação Rio Bonito - Rio Grande do Sul -Brasi1. Pesquisas. Porto Alegre (2):37-48, 1973.

32. ZAJIC, J. Microbial biogeochemistry, New York, Academic, 1969. $345 \mathrm{p}$.

Recebido em outubro, 1983; aceito em novembro, 1983. 
